Trikonomika

Volume 20, No. 1, June 2021, Page. 1-10

ISSN 1411-514X (print) / ISSN 2355-7737 (online)

\title{
DIRECT FERTILIZER SUBSIDIES ON PRODUCTION AND HOUSEHOLD INCOME IN INDONESIA
}

\author{
Arrief Chandra Setiawan ${ }^{1}$, Djoko Mursinto ${ }^{2}$, Tri Haryanto ${ }^{3}$ \\ ${ }^{1}$ arriefcs@gmail.com \\ Airlangga University \\ Jl. Airlangga No.4 - 6, Airlangga, Kec. Gubeng, Kota SBY, Jawa Timur
}

received: 26/3/21; revised: 21/6/21; approved: 28/6/21

\begin{abstract}
This research aims to analyze the effect of fertilizer subsidies on the production and household income of rice farming in Indonesia using the 2017 crops business cost structure survey data. Utilizing the Ordinary Least Square (OLS) method, this research shows that rice farming households that received fertilizer subsidies have higher production and income than households that did not receive subsidies. Simultaneously, in the Two-Stage Least Square (TSLS) method, the usage of the ownership status of a household residential building as an instrument for the fertilizer subsidy variable is considered inaccurate so that it cannot answer the research objectives.
\end{abstract}

Keywords: fertilizer subsidies; rice production; farmer income; Indonesia; Ordinary Least Square

\section{INTRODUCTION}

The development of the agricultural sector is essentially aimed at improving the welfare of farmers and ensuring the achievement of food security and even food sovereignty, for every Indonesian citizen. As an effort to achieve it, the government intervened by providing fertilizer subsidies to farmers. Nominally, the budget allocation for fertilizer subsidies is quite large. It is around 20 to nearly 40 percent of the total food security budget for 2010-2019. Meanwhile, the realization of the distribution of fertilizer subsidies itself continues to increase from IDR 18.4 trillion in 2010 to IDR 34.3 trillion in 2019 (Directorate General of Budget, Ministry of Finance, 2020). Periodically, this policy is considered to be increasingly burdensome to state finances. Risks arising from increased fluctuations in international gas prices and the volatility of the Rupiah exchange rate against the US Dollar prompted an increase in the number of subsidies, which exacerbated pressure on state finances (Ministry of Finance, 2015).

Considered to be burdensome to state finances, this policy was also deemed ineffective in increasing productivity. Based on a study conducted by the National Team for the Acceleration of Poverty Reduction (TNP2K), the fertilizer subsidies increased by 1,088 percent during 2006-2015. However, the productivity and value-added of the agricultural sector increased by only 14 and 38 percent, respectively. Certainly, in 20182019, when fertilizer subsidies increased by 2.07 percent (Directorate General of Budget, Ministry of Finance, 2020), rice (Milled Dry Grain) production actually decreased by 7.76 percent from 59.2 million tons in 2018 to 54.60 million tons in 2019(Statistics Indonesia, 2020). However, rice production decreased from 33.94 to 31.31 million tons in the same period (Statistics Indonesia, 2020).

Many researches on fertilizer subsidies have been carried out. Several studies have shown that fertilizer subsidies can increase agricultural productivity and household income (Ranathilaka and Arachchi, 2019; Mulyadiana, et al., 2018; Ali, et al., 2019; Wang, et al., 2019; Wossen, et al., 2017; Komarek, et al., 2017), and also reduce poverty (Wang, et al., 2019; Wossen, et al., 2017).

According to Herath, et al (2013), the intervention in the form of providing fertilizer subsidies, especially chemical fertilizers, will increase the use of that fertilizer so in the end the agriculture production will also increase. Unfortunately, the increase in the use of chemical fertilizers also has an impact on the contamination of agricultural products (Sharma and Singhvi, 2017), a gradual decline in the health quality of workers in the agricultural sector due to interactions with chemical inputs (Kishi, et al, 1995), land degradation (Pretty, J., 2008), and increasing CO2 emissions that contribute to climate change (Bartelings, et al., 2016).

Meanwhile, other research shows that fertilizer subsidies increase production but the increase is smaller than expected (Jaynea, et al., 2018). Teka and Lee (2020) and Rahmanta, et al., (2019) found that subsidies have no 
effect on agricultural household income. Hu and Antle (1993) concluded that subsidies do not always increase productivity. Kanthilanka and Weerahewa (2018) themselves conclude that subsidies do not affect production.

Studies analyzing the effect of fertilizer subsidies on farmer production and income in Indonesia at the micro (household or farmer) level are still quite limited. The studies are also regional because they only cover certain areas such as Karanganyar (Mulyadiana, et al., 2018) and Serdang Bedagai (Rahmanta, et al., 2019). Therefore, a study with a broader scope such as a national level is needed.

Apart from broadening the coverage, this study also tries to accommodate the possibility of endogeneity in the subsidy variable (Wossen, et al., 2017; Teka and Lee, 2020) which has the potential to create bias in concluding the effect of fertilizer subsidies on rice production and household income. This has not been accommodated in previous studies.

The effect of agricultural input subsidies on the demand and supply of agricultural inputs and supply of agricultural output is shown in the Figure 1 (Bosch, 1985). In an output market, S(Q) shows the output supply curve before the subsidy, $\mathrm{S}(\mathrm{Q})$ ' shows the output supply curve after input subsidies are applied, and $\mathrm{D}(\mathrm{Q})$ shows the demand for output. Moreover, in the input market, $S(X) D$ shows the domestic supply of agricultural inputs before input subsidies are applied, $\mathrm{S}(\mathrm{X})^{\prime} \mathrm{D}$ shows the domestic supply of agricultural inputs after input subsidies are applied, $\mathrm{S}(\mathrm{X}) \mathrm{W}$ represents the total supply (domestic and foreign) of agricultural inputs, and $\mathrm{D}(\mathrm{X})$ represents the demand for agricultural inputs.

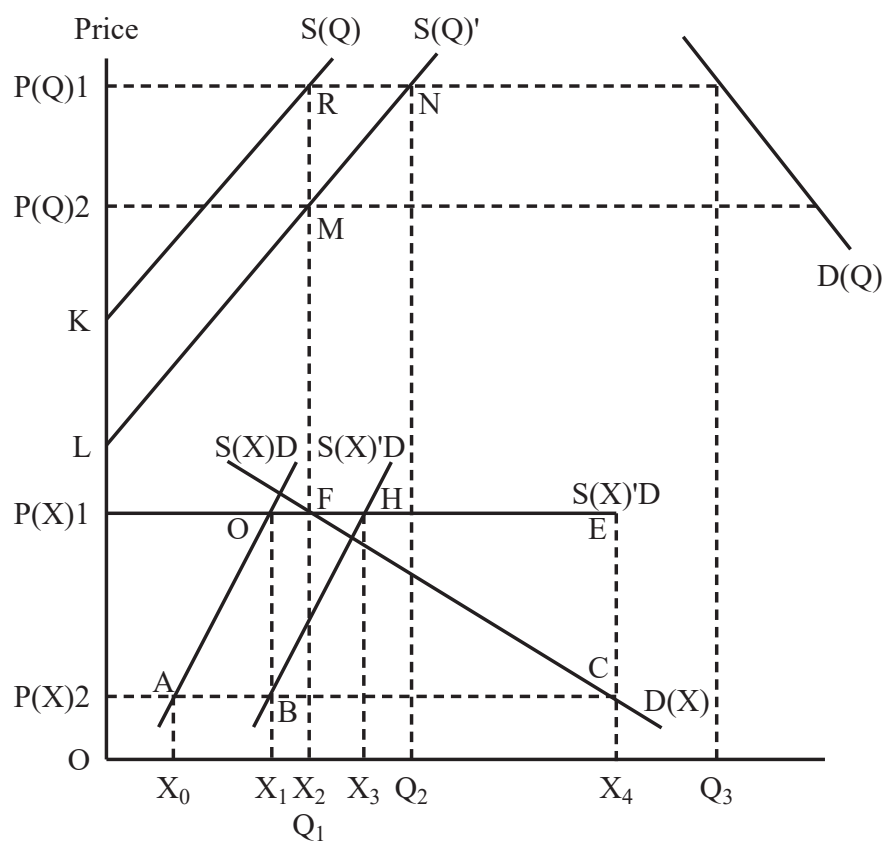

Source: Bosch (1985:92)

Figure 1. The Effect of Agricultural Input Subsidies on the Input Market and Output Supply

The conditions before the introduction of input subsidies are described as follows: (1) Domestic producers of agricultural inputs produce as much as $\mathrm{X}_{1}$ at the price level $\mathrm{P}(\mathrm{X}) 1 ;(2)$ At the price level $\mathrm{P}(\mathrm{X}) 1$, farmers need as much as $\mathrm{X}_{2}$ input. Because this input is more than the production capacity of domestic producers, which is $\mathrm{X}_{1}$, the difference which is $\mathrm{X}_{2}-\mathrm{X}_{1}$ is met by imports; (3) By using an input of $\mathrm{X}_{2}$, farmers can produce an output of Q1 at the price level $\mathrm{P}(\mathrm{Q}) 1$; (4) At the price level $\mathrm{P}(\mathrm{Q}) 1$, the output required by consumers is Q3, where Q3 is greater than the production capacity of domestic farmers by Q1. Therefore, the difference between Q3 and Q1 is fulfilled by imports.

When the government imposes input subsidies, the changes in supply and demand in the input and output markets are explained as follows: (1) The input price will decrease from $\mathrm{P}(\mathrm{X}) 1$ to $\mathrm{P}(\mathrm{X}) 2$. At the price level $\mathrm{P}(\mathrm{X}) 2$, the input demand from farmers will increase to $\mathrm{X}_{4}$. Therefore, the input subsidy will increase the input demand by $\mathrm{X}_{4}-\mathrm{X}_{2} ;(2)$ This increase in demand causes the input supply curve to shift to the right from $\mathrm{S}(\mathrm{X}) \mathrm{D}$ to $\mathrm{S}(\mathrm{X})$ 'D. as a result, at the price level $\mathrm{P}(\mathrm{X}) 2$, the amount of input produced by domestic producers remains at $\mathrm{X} 1$. The constant amount of input produced by domestic producers coupled with an increase in input demand by farmers causes an increase in imports for input goods; (3) The increase in input usage by farmers causes the output supply curve to shift to the right from $\mathrm{S}(\mathrm{Q})$ to $\mathrm{S}(\mathrm{Q})^{\prime}$. At the price level $\mathrm{P}(\mathrm{Q}) 1$, the amount of output produced by farmers has increased from Q1 to Q2. With a constant demand for output, an increase in output 
by farmers has implications for decreasing imports of output goods; (4) Based on the above mechanism, the amount of subsidy borne by the government is $\mathrm{X}_{4}[\mathrm{P}(\mathrm{X}) 1-\mathrm{P}(\mathrm{X}) 2]$; (5) With the existence of a subsidy of $\mathrm{X}_{4}$ $[\mathrm{P}(\mathrm{X}) 1-\mathrm{P}(\mathrm{X}) 2]$, the surplus which can be enjoyed by farmers is increased by the area of KLNR. Meanwhile, the surplus which can be enjoyed by domestic input producers is as big as the ABHG area.

The output supply curve will shift from $S(Q)$ to $S(Q)$ ' as: Parallel, if there is no change in production efficiency. Convergent, if the subsidy policy is accompanied by a decrease in production efficiency. Divergent, if the subsidy policy is accompanied by an increase in production efficiency.

\section{METHODS}

This study uses multiple linear regressions to determine the effect of fertilizer subsidies on production and income. The regression model in this study is a modification of the model used by Wossen et al. (2017) which is described as follows:

production $_{\mathrm{i}}=\beta_{0}+\beta_{1}$ subsidi $_{\mathrm{i}}+\beta_{2}$ education $_{\mathrm{i}}+\beta_{3}$ age $_{\mathrm{i}}+\beta_{4}$ nart $_{\mathrm{i}}+\beta_{5}$ community $_{\mathrm{i}}+\beta_{6}$ partnership $_{\mathrm{i}}+\beta_{7}$ target $_{\mathrm{i}}+\beta_{8}$ irrigation $_{\mathrm{i}}$ $+\sum_{\mathrm{j}=1}^{33} \beta_{9 \mathrm{j}} \operatorname{prov}_{\mathrm{ij}}+\mathrm{e}_{\mathrm{i}}$

income $_{\mathrm{i}}=\beta_{0}+\beta_{1}$ subsidi $_{\mathrm{i}}+\beta_{2}$ education $_{\mathrm{i}}+\beta_{3}$ age $_{\mathrm{i}}+\beta_{4}$ nart $_{\mathrm{i}}+\beta_{5}$ community $_{\mathrm{i}}+\beta_{6}$ partnership $_{\mathrm{i}}+\beta_{7}$ target $_{\mathrm{i}}+\beta_{8}$ irrigation $_{\mathrm{i}}+\sum^{33}{ }_{\mathrm{j}=1} \beta_{9 \mathrm{j}} \operatorname{prov}_{\mathrm{ij}}+\mathrm{e}_{\mathrm{i}}$

whereas:

production : harvested dry grain (quintals per planting season)

income : income (thousand Rupiah per hectare per planting season)

subsidy $\quad:$ dummy with value $=1$ if receiving subsidies, and 0 if vice versa

education : dummy with value $=1$ if the main farmer has education, and 0 if vice versa

age $\quad:$ the age of the main farmer

nart : number of household members

community: dummy with value $=1$ if members of farmer group and 0 if vice versa

partnership : dummy with value $=1$ if forging a partnership, and 0 if vice versa

target : dummy with value $=1$ if it is the target recipient of the subsidy, and 0 if vice versa

irrigation : dummy with value $=1$ if using irrigation, and 0 if vice versa

prov : dummy of province

In the regression model above, $i$ represents the household, $\mathrm{j}$ represents the province, $\beta_{0}$ shows the constant/ intercept, $\beta_{1}$ to $\beta_{8}$ shows the regression coefficient/slope for each explanatory variable, $\mathrm{j}$ shows the provinces where Papua is the benchmark, and $\mathrm{e}_{\mathrm{i}}$ is an error. The dependent variables in this study are production and income. Production is the total output of rice cultivation in the form of Harvested Dry Grain which is calculated during one growing season. Meanwhile, income is the total production value of the main product (Harvested Dry Grain) and byproducts (husks) which have economic value. The subsidy, as the main explanatory variable, is a dummy which will be worth 1 if the household receives a fertilizer subsidy and 0 if it does not. This variable is not calculated based on the amount of production value due to the unavailability of data.

Other explanatory variables are education, age, number of household members (nart), community, partners, targets, and irrigation. Education is measured by the highest certificate held by the main farmer. Age is the age of the main farmer at the time of the last birthday. The number of household members is the number of all people who usually live in a household (head of the household, husband/wife, children, son/daughter in law, grandchildren, parents/in-laws, other relatives, housemaids who stay overnight or other household members) both those who are at home and those who are temporarily not at home. Community shows the membership of one household member in the farmer group. Partnership (partner) indicates whether the household has a business partnership with a State-owned enterprise, Municipally-owned enterprise, private companies, or cooperative. The target indicates whether the household is the target recipient of the fertilizer subsidy or not. A household is categorized as a target if the cultivated agricultural land is a maximum of 2 hectares. Irrigation shows whether an agricultural business uses irrigated land or not.

This study also utilizes provincial dummy variables to control for differences in characteristics between provinces, such as differences in the application of regional development policies which arise as a result of decentralization or differences in natural resource endowment (soil fertility, biodiversity wealth, weather). Various studies (Gordon and Resosudarmo, 2019; Kis Katos and Sparrow, 2015), especially in the field of development and regional economics in Indonesia, explain that this regional control variable is very important to be included in the empirical model because of the considerable variation in characteristics in Indonesia. 
Following the study of Wossen, et al. (2017) which used instrument variables to overcome the problem of endogeneity in subsidized variables, this study also strives to do the same thing. Wossen, et al. (2017) used the duration farmers lived in the village as an instrument variable as a result of data limitations while this study uses a residential building ownership approach. Households that have lived in an area for a long time, thus having large social and political capabilities, generally have occupied their residence. According to Wossen, et al. (2017), the longer a household lives in the village, the greater its social and political capabilities are, so that it has a greater chance of obtaining subsidies. The 2SLS (Two-Stage Least Square) analysis tool was utilized to test the causality relationship between the subsidy variable and the residential building ownership variable. The estimation model at the first stage is written as follows:

subsidy $_{\mathrm{i}}=\alpha_{0}+\alpha_{1}$ ownership $_{\mathrm{i}}+\alpha_{2}$ education $_{\mathrm{i}}+\alpha_{3}$ education $_{\mathrm{i}}+\alpha_{4}$ age $_{\mathrm{i}}+\alpha_{5}$ nart $_{\mathrm{i}}+\alpha_{6}$ community $_{\mathrm{i}}+\alpha_{7}$ partnership $_{\mathrm{i}}+\alpha_{8}$ target $_{\mathrm{i}}+\alpha_{9}$ irrigation $_{\mathrm{i}}+\sum_{\mathrm{j}=1}^{33} \alpha_{10 \mathrm{j}} \operatorname{prov}_{\mathrm{ij}}+\mathrm{v}_{\mathrm{i}}$

Moreover, the estimation model at the second stage follows equations (1) and (2). This study utilizes secondary data. The data is sourced from the results of the Crops Business Cost Structure Survey (SOUT) conducted in 34 provinces and 503 municipalities/cities in 2017. The unit of analysis included in this study were 152,778 households in rice farming whose main farmers were aged 15 years and over.

\section{RESULTS}

From an economic perspective, the average household income from rice farming is IDR $15.36 \mathrm{million} / \mathrm{ha} /$ planting season (Table 1). If the average rice planting season is around four months, the average income per month is IDR $3.84 \mathrm{million} / \mathrm{ha} /$ planting season. Meanwhile, the average production during one growing season reached 20.29 quintals or 5.07 quintals per month.

The percentage of households that received fertilizer subsidies reached 47.13 percent. Demographically, the average age of the main farmers in a sample of 152,778 rice farming households is 50.87 years. Moreover, in each agricultural business household, there will be 4 household members on average.

Table 1. Descriptive Statistics of Several Main Research Variables

\begin{tabular}{lccccc}
\hline \multicolumn{1}{c}{ Variables } & Observation & Average & Std. Deviation & Min & Max \\
\hline income (thousand rupiah/Ha/planting season) & 152.778 & $15.358,24$ & $8.296,04$ & 0,8750 & $108.333,30$ \\
production (quintal/planting season) & 152.778 & 20,29 & 22,99 & 0,0500 & $1.200,00$ \\
subsidy (dummy) & 152.778 & 0,47 & 0,50 & 0 & 1 \\
nart (people) & 152.778 & 4,04 & 1,65 & 1 & 21 \\
age (years) & 152.778 & 50,87 & 11,76 & 15 & 99 \\
community (dummy) & 152.778 & 0,59 & 0,49 & 0 & 1 \\
partnership (dummy) & 152.778 & 0,01 & 0,09 & 0 & 1 \\
irrigation (dummy) & 152.778 & 0,38 & 0,49 & 0 & 1 \\
target (dummy) & 152.778 & 0,44 & 0,50 & 0 & 1 \\
residential building ownership & 152.778 & 0,96 & 0,19 & 0 & 1 \\
\hline
\end{tabular}

Source: Statistics Indonesia (2017)

In general, the amount of production and income for households that receive subsidies is greater than for households that do not receive subsidies. Significant differences are seen in land productivity and production. In terms of total production, households which received subsidies were able to produce 5.65 quintals more than households that did not receive subsidies (Table 2). This is reasonable because those who receive subsidies tend to use larger fertilizers so that the resulting output is also greater.

Table 2. The Average of Business Productivity, land Productivity, and Income in Rice Farming Households Samples

\begin{tabular}{lcc}
\hline \multicolumn{1}{c}{ Variables } & Did Not Receive Subsidies & Received Subsidies \\
\hline Business Productivity (The ratio of the total output value to the total cost of production) & 1,52 & 1,56 \\
Land productivity (Quintal/ha/planting season) & 32,78 & 41,30 \\
Production (Quintal/planting season) & 17,63 & 23,28 \\
Income (Thousand Rupiah/ha/planting season) & $14.009,11$ & $16.871,49$ \\
\hline
\end{tabular}

Source: SOUT 2017, processed 
With the difference in land productivity of 8.25 quintals/ha/planting season and it was assumed that the purchase price of GKP at the farmer level was IDR 3,750/kilogram (according to Presidential Instruction No. 5 of 2015 and has not changed in 3 years), on average, households that received subsidies should receive an income of IDR 3.2 million more than households that did not receive subsidies for each hectare of land cultivated per planting season. There was only a difference of IDR 2.8 million/hectare/planting season between the two groups. From this fact, there was an indication that the purchase price of GKP at the farm level tended to be higher in households that did not receive subsidies compared to households that received subsidies. This was confirmed by the results of SOUT 2017 processing which showed that the average purchase price of GKP for households that did not receive subsidies reached IDR 4,532/kg. Meanwhile, for households that received subsidies, the average purchase price was only IDR 4,200/kg.

In terms of land ownership, on average, the area of agricultural land managed by rice farming households reached 1.37 hectares. Of these, only 0.69 hectares were used for rice cultivation while the rest was generally used for secondary crops and horticultural commodities. If viewed from the business productivity, it could be seen that the average business productivity in the household sample was 1.54 which means that with a capital of IDR 1 million, the household will receive an income of IDR 1.54 million. Business productivity with a value of more than 1 indicates that on average, rice farming is still profitable for agricultural business households.

Tables 3 and 4 show some differences between the OLS and 2SLS estimation results. First, the OLS estimation results show that fertilizer subsidies have a positive effect on production and income of the rice farming households. Meanwhile, in the 2SLS estimation, there is no evidence that fertilizer subsidies affect the two dependent variables. Second, the 2SLS estimation produces a regression coefficient and standard error that is much greater than the OLS estimation. Third, in the OLS estimation, all explanatory variables have a significant effect on the dependent variable whereas, in the 2SLS estimation, only education, partnerships, and the status of the target recipient of the subsidy affect the production and just education affect income. Fourth, in the OLS estimation, partnership and irrigation are variables with regression coefficient values that are always in the top 3 compared to other explanatory variables. Meanwhile, in the 2SLS estimation, it is the subsidy and community variables that always occupy the position of the three variables with the largest regression coefficient values in the four estimation models.

Table 3. The Fertilizer Subsidy Regression Coefficient on Production and Income using the OLS Method

\begin{tabular}{|c|c|c|c|c|c|c|}
\hline \multirow[b]{2}{*}{ Explanatory Variables } & \multicolumn{3}{|c|}{$\begin{array}{l}\text { Dependent Variables: Production } \\
\text { (quintal/planting season) }\end{array}$} & \multicolumn{3}{|c|}{$\begin{array}{c}\text { Dependent Variables: Income } \\
\text { (Thousand Rupiah/ha/planting season) }\end{array}$} \\
\hline & coefficient & Std. Error & p-value & coefficient & Std. Error & p-value \\
\hline subsidy & & & & & & \\
\hline $\begin{array}{l}1=\text { received } \\
0=\text { did not receive } \\
\text { education }\end{array}$ & $3,296 * * *$ & 0,1206 & 0,0000 & $1429,887 * * *$ & 40,9353 & 0,0000 \\
\hline $\begin{array}{l}1>\text { junior high school/equal } \\
0<=\text { junior high school/equal) }\end{array}$ & $3,601 * * *$ & 0,1512 & 0,0000 & $1583,363 * * *$ & 51,3129 & 0,0000 \\
\hline age & $0,025 * * *$ & 0,0049 & 0,0000 & $22,308 * * *$ & 1,6678 & 0,0000 \\
\hline $\begin{array}{l}\text { nart } \\
\text { community }\end{array}$ & $0,265 * * *$ & 0,0345 & 0,0000 & $-65,646 * * *$ & 11,7094 & 0,0000 \\
\hline $\begin{array}{l}1=\text { member of farmer group } \\
0=\text { not a member of farmer group } \\
\text { partnership }\end{array}$ & $5,094 * * *$ & 0,1214 & 0,0000 & $886,998 * * *$ & 41,18715 & 0,0000 \\
\hline $\begin{array}{l}1=\text { in partnership } \\
0=\text { not in any partnership } \\
\text { target }\end{array}$ & $11,023 * * *$ & 0,6401 & 0,0000 & $1512,828 * * *$ & 217,1896 & 0,0000 \\
\hline $\begin{array}{l}1=\text { target recipient }(\text { land }<=2 \text { ha }) \\
0=\text { not a target recipient }(\text { land }>2 \text { ha) } \\
\text { irrigation }\end{array}$ & $-6,808 * * *$ & 0,1154 & 0,0000 & $888,023 * * *$ & 39,1522 & 0,0000 \\
\hline $\begin{array}{l}1=\text { irrigation } \\
0=\text { non- irrigation }\end{array}$ & $7,151 * * *$ & 0,1225 & 0,0000 & $4184,466^{* * *}$ & 41,5731 & 0,0000 \\
\hline $\begin{array}{l}\text { Dummy Province } \\
\text { constant }\end{array}$ & $\begin{array}{c}\text { Yes } \\
33,745^{* * *}\end{array}$ & 0,7317 & 0,0000 & $\begin{array}{c}\text { Yes } \\
11.530,627^{* * *}\end{array}$ & 248,2695 & 0,0000 \\
\hline Adjusted $\mathrm{R}^{2}$ & & 0,1325 & & & 0,234 & \\
\hline Number of Observations & & 152.778 & & & 152.778 & \\
\hline
\end{tabular}

Source : SOUT 2017, processed

Notes $\quad: * * *$ significant at alpha 0,$01 ; * *$ significant at alpha 0,$05 ; *$ significant at alpha 0,1 
Table 4. The Fertilizer Subsidy Regression Coefficient on Production and Income using the 2SLS Method

\begin{tabular}{|c|c|c|c|c|c|c|}
\hline \multirow[b]{2}{*}{ Explanatory Variables } & \multicolumn{3}{|c|}{$\begin{array}{l}\text { Dependent Variables: Production } \\
\text { (quintal/planting season) }\end{array}$} & \multicolumn{3}{|c|}{$\begin{array}{l}\text { Dependent Variables: Income } \\
\text { (Thousand Rupiah/ha/planting season) }\end{array}$} \\
\hline & coefficient & Std. Error & p-value & coefficient & Std. Error & p-value \\
\hline subsidy & & & & & & \\
\hline $\begin{array}{l}1=\text { received } \\
0=\text { did not receive } \\
\text { education }\end{array}$ & $-366,765$ & 508,6085 & 0,471 & $102.246,3$ & $139.169,4$ & 0,463 \\
\hline $\begin{array}{l}1>\text { junior high school/equal } \\
0<=\text { junior high school/equal) }\end{array}$ & $3,792 * * *$ & 1,2248 & 0,002 & $1.531,3 * * *$ & 335,1 & 0,000 \\
\hline age & $-0,035$ & 0,0911 & 0,704 & 38,6 & 24,9 & 0,121 \\
\hline $\begin{array}{l}\text { nart } \\
\text { community }\end{array}$ & $-1,252$ & 2,1035 & 0,552 & 347,8 & 575,6 & 0,546 \\
\hline $\begin{array}{l}1=\text { member of farmer group } \\
0=\text { not a member of farmer group } \\
\text { partnership }\end{array}$ & 93,495 & 121,5007 & 0,442 & $-23.196,2$ & $33.245,9$ & 0,485 \\
\hline $\begin{array}{l}1=\text { in partnership } \\
0=\text { not in any partnership } \\
\text { target }\end{array}$ & $14,880 * *$ & 7,3314 & 0,042 & 461,9 & $2.006,1$ & 0,818 \\
\hline $\begin{array}{l}1=\text { target recipient }(\text { land }<=2 \text { ha }) \\
0=\text { not a target recipient }(\text { land }>2 \text { ha }) \\
\text { irrigation }\end{array}$ & $-4,957 *$ & 2,7029 & 0,067 & 383,7 & 739,6 & 0,604 \\
\hline $\begin{array}{l}1=\text { irrigation } \\
0=\text { non- irrigation }\end{array}$ & 38,444 & 43,0194 & 0,372 & $-4.340,7$ & $11.771,3$ & 0,712 \\
\hline $\begin{array}{l}\text { Dummy Province } \\
\text { constant } \\
\text { Number of Observations }\end{array}$ & $\begin{array}{c}\text { Yes } \\
213,949\end{array}$ & $\begin{array}{c}247,7383 \\
152.778\end{array}$ & 0,388 & $\begin{array}{c}\text { Yes } \\
-37.562,7\end{array}$ & $\begin{array}{l}67.788,1 \\
152.778\end{array}$ & 0,579 \\
\hline
\end{tabular}

Source : SOUT 2017, processed

Notes $\quad: * * *$ significant at alpha 0,$01 ; * *$ significant at alpha 0,$05 ; *$ significant at alpha 0,1

The endogeneity test results show that there is no endogeneity to the subsidy variable in the model used to estimate the effect of subsidies on business productivity (the ratio of the total output value to the total input value). Meanwhile, endogeneity is found in the model used to estimate the effect of subsidies on production and income (Table 5).

Wooldridge (2001) explains that, in an econometric context, an explanatory variable is said to be endogenous if the variable is correlated with the error generated by the estimation model. In this study, the subsidy variable is endogenous because the variable is correlated with an error. This error is generated from the model used to estimate the effect of subsidies on production and income.

Furthermore, Wooldridge (2001) also explains that one of the factors which cause endogeneity is the omitted variables which occur when the researcher does not include one or more variables that should be in the estimation model. This usually occurs when data on these variables are not available or cannot be obtained. In this study, it is assumed that the omitted variables occur because the land fertility variable is not included in the estimation model. Moreover, based on a study by Ebanyat, et al (2010), soil fertility strongly affects land productivity which in turn affects total production and income. However, this variable cannot be included in the estimation model because of the unavailability of data, especially at the household level.

Table 5. The Endogeneity Test Results

\begin{tabular}{lcccc}
\hline & \multicolumn{2}{c}{ Wu Hausman Test } & \multicolumn{2}{c}{ Durbin Wu Hausman Test } \\
\cline { 2 - 5 } Type of Model being tested & Test Statistics & p-value & Test Statistics & p-value \\
\hline Estimation Model of the subsidies effect on production & 33,13509 & 0,00000 & 33,13722 & 0,00000 \\
Estimation Model of the subsidies effect on income & 21,36188 & 0,00000 & 21,36491 & 0,00000 \\
\hline
\end{tabular}

Notes: Ho: the subsidy variable is exogenous

According to Greene (2012), the existence of endogeneity in the model causes the resulting regression coefficient to be inconsistent so that it cannot be used to explain the causal relationship between the explanatory variables and the dependent variable. To minimize the impact of endogeneity on subsidized variables, Gilbert 
and Jayne (2015) use proxy variable which is shock into the model such as the average rainfall for five years and rainfall this year. In this study, the unavailability of shock variable data causes endogeneity to be overcome by using proxy variables. According to Wooldridge (2001), the use of instrument variables will be better than using proxy variables if the instrument variables used are closely correlated with explanatory variables which are endogenous but not correlated with the dependent variable. Therefore, this study strives to use instrument variables to overcome emerging endogeneity.

In determining the instrument variable, Wossen, et al. (2017) used the duration of the household lived in the current residence as the instrument variable. Wossen, et al. (2017) argue that the longer the household lives in the village at this time, the greater the household's capability to obtain subsidized assistance. By applying the arguments of Wossen, et al. (2017), this study uses the variable of residential building ownership because in general, people who have lived in an area for a long time tend to have proper buildings with the status of their own.

After estimating, the results show that the variable of residential building ownership is not statistically correlated with the subsidy variable. This means that the criteria for residential building ownership, as an instrument variable, which must have a strong correlation with the subsidy variable, which is endogeneous, cannot be fulfilled. It is suspected that this is what causes the estimation of the value of the subsidized variable, using instrument variables, to be overestimated, causing quite a large difference between the OLS and 2SLS estimation results as previously explained (Table 6).

If the instrument variable does not have a strong correlation with the explanatory variable experiencing endogeneity, the use of the instrument variable will result in a more biased estimate than the use of OLS (Wooldridge, 2001). Therefore, the analysis of the effect of subsidies on production, and income is only guided by the estimation results of the OLS method. Moreover, the resulting regression coefficient only illustrates the correlation and not the causality relationship between subsidies on production, and income.

Table 6. Residential Building Ownership Regression Coefficient on Status of Fertilizer Subsidy Receipt in Agricultural Business Households

\begin{tabular}{|c|c|c|c|}
\hline \multirow[b]{2}{*}{ Explanatory Variables } & \multicolumn{3}{|c|}{$\begin{array}{c}\text { Dependent Variables: Subsidy } \\
1 \text { = Received } \\
0=\text { Did not received } \\
\text { Model OLS (First Stage 2SLS) }\end{array}$} \\
\hline & coefficient & Std. Error & p-value \\
\hline \multicolumn{4}{|l|}{ subsidy } \\
\hline $1=$ received & $-0,0045$ & 0,0062 & 0,463 \\
\hline \multicolumn{4}{|l|}{$\begin{array}{l}0=\text { did not receive } \\
\text { education }\end{array}$} \\
\hline $\begin{array}{l}1>\text { junior high school/equal } \\
0<=\text { junior high school/equal) }\end{array}$ & 0,0004 & 0,0032 & 0,892 \\
\hline age & $-0,0001$ & 0,0001 & 0,138 \\
\hline nart & $-0,0041 * * *$ & 0,0007 & 0,000 \\
\hline \multicolumn{4}{|l|}{ community } \\
\hline $1=$ member of farmer group & $0,2389 * * *$ & 0,0025 & 0,000 \\
\hline \multicolumn{4}{|l|}{$\begin{array}{l}0=\text { not a member of farmer group } \\
\text { partnership }\end{array}$} \\
\hline $1=$ in partnership & 0,0104 & 0,0135 & 0,442 \\
\hline \multicolumn{4}{|l|}{$0=$ not in any partnership } \\
\hline $1=$ target recipient $($ land $<=2 \mathrm{ha})$ & $0,005^{* *}$ & 0,0024 & 0,041 \\
\hline \multicolumn{4}{|l|}{$0=$ not a target recipient (land $>2$ ha) } \\
\hline $1=$ irrigation & $0,0845^{* * *}$ & 0,0026 & 0,000 \\
\hline \multicolumn{4}{|l|}{$0=$ non - irrigation } \\
\hline Dummy Province & Yes & & \\
\hline constant & $0,4908 * * *$ & 0,0164 & 0,0000 \\
\hline Number of Observations & & 152.778 & \\
\hline
\end{tabular}

Source : SOUT 2017, processed

Notes $\quad: * * *$ significant at alpha 0,$01 ; * *$ significant at alpha 0,$05 ; *$ significant at alpha 0,1 


\section{DISCUSSIONS}

Based on the OLS estimation results, households that received fertilizer subsidies had higher average production and income than households that did not receive fertilizer subsidies. In every one hectare of land in one planting season, households that received subsidies were able to produce Harvested Dry Grain (GKP) by 3.29 quintals higher than those who did not receive subsidies. In terms of income, households that received subsidies earned IDR 1.43 million more from rice cultivation than those who did not receive subsidies for each hectare of land during one planting season. These results certainly add to the empirical evidence that shows a positive relationship between fertilizer subsidies on production and income as has been conducted by Ali et al (2019); Wossen, et al. (2017), Ranathilaka and Arachchi (2019); Jaynea (2018); Ginige, S. R., and Cooray, N. S. (2020); Kanthilanka, H., and Weerahewa, J (2018); Komarek, et al. (2017), Wang, et al. (2019); Wijetunga and Saito (2017); Herath, et al. (2013); Hu, F., and Antle, J. M. (1993); and Mulyadiana, et al. (2018).

Another interesting thing is that although these fertilizer subsidies have a positive correlation on production and income, the magnitude of the effect generated is still smaller than expected (Jaynea, 2018). For Indonesia, based on the results of the National Team for the Acceleration of Poverty Reduction (TNP2K), although fertilizer subsidies had increased by 1,088 percent during 2006-2015, the productivity of the agricultural sector had only increased by 14 percent and its added value had only increased by 38 percent. In this regard, it would be more interesting if the explanatory variable analyzed was the number of fertilizer subsidies received by farmers. Ideally, the amount of this subsidy is expressed as the total value of fertilizer subsidies received by farmers in rupiah units during a certain period. However, in this study, this could not be done due to information on the total value of subsidies received by farmers was not available. The only information available was whether a household received subsidized fertilizer or not. Therefore, this study only uses the status variable of fertilizer subsidy receipt and not the value of the subsidy received.

Meanwhile, Wang, et al. (2018) explained that optimizing the benefits of fertilizer subsidies is not only related to the criteria for recipients and distribution mechanisms but also must pay attention to the type of fertilizer subsidized and its composition because different plants require different types and compositions of fertilizers as well. In the case of rice commodities, different rice commodities likely require different types and compositions of fertilizers. Therefore, it is important to include the rice variety of data used in the estimation model. This study was not conducted because the rice variety data was still considered invalid. This is very possible because of the difference in language between regions in Indonesia so that the same rice variety can be called with different names for different regions.

Related to the period, Gerber (2016) found that the positive effect of fertilizer subsidies on increasing productivity and production only occurs in the short term. Meanwhile, in the long term, fertilizer subsidies are no longer effective in increasing productivity and production. This is related to the types of subsidized fertilizers which are dominated by inorganic fertilizers. The use of inorganic fertilizers in the long term has a negative impact which damaging to organic minerals in the soil, which results in decreasing soil fertility, which has implications for decreased production. The same thing was concluded by Gilbert and Jayne (2017) and Li, et al. (2014). This is very interesting to be studied more deeply; however, the availability of cross-sectional data causes this analysis to not be conducted in this study

Based on the analysis that has been conducted, the fertilizer subsidy policy for rice farming households is still needed as part of efforts to increase rice production and increase farmers' income. However, the mechanism for determining beneficiaries still requires review. If previously beneficiaries were only proposed by farmer groups, it would be better if the proposal was verified by an independent party, for example from the local Agriculture Service. Thus, the possibility of inclusion errors can be minimized.

Moreover, fertilizer subsidies are not the only way to increase rice production and farmers' income. This is related to government budget constraints, the issue of the negative impact of using chemical fertilizers on soil fertility in the long term, and the imbalance of the increase in production that occurs with the amount of the subsidy budget issued. Therefore, an alternative policy is needed that can be implemented simultaneously with the fertilizer subsidy policy.

Empowerment of the private sector in the form of partnerships with agricultural business households is one alternative policy that can be selected. First, this policy further optimizes the role of the private sector so that it does not overly burden state finances. Second, based on the regression results, the regression coefficient for partnership is quite large and ranks as the top 3 in land productivity, production, income, and business productivity models. Third, the existence of previous empirical research shows a positive influence between partnerships and farmers' production and income (Ton, et al., 201; Nguyen, et al., 2015). 


\section{CONCLUSIONS}

This study aims to analyze the effect of fertilizer subsidies on the production and income of rice farming households in Indonesia. This study was conducted using a micro analysis unit totalling 152,778 rice farming households. Compared to previous studies in Indonesia, this study uses data that is more complete in scope and has considered the existence of endogeneity. Based on this research, fertilizer subsidies are known to have a positive correlation with production and income. However, there is not enough evidence to conclude that fertilizer subsidies encourage the increase of the three variables above. The problem of endogeneity in the variable fertilizer subsidy is the reason why it is not certain that there is a causal relationship between fertilizer subsidies on land productivity, production, and income.

\section{REFERENCES}

Ali, A., Rahut, D. B., \& Imtiaz, M. 2019. Affordability Linked with Subsidy: Impact of Fertilizers Subsidy on Household Welfare in Pakistan. Sustainability, 11(19), 5161.

Bartelings, H., Kavallari, A., Meijil, H., \& Lampe, M. 2016. Estimating the Impact of Fertilizer Support Policies: A CGE Approach. Presented at the 19th Annual Conference on Global Economic Analysis, Washington DC, USA.

Bosch, R. A. 1985. The Economics of Agricultural Subsidies. Niewveen: Wageningen University.

BPS. 2020. Luas Panen dan Produksi Padi di Indonesia 2019 (Hasil Survei Kerangka Sampel Area). Berita Resmi Statistik No. 06/02/Th. XXIII, hal. 1-12.

Direktorat Jenderal Anggaran Kementerian Keuangan. 2020. Annual Report 2019. Jakarta: Kementrian Keuangan Direktorat Jenderal Pajak.

Ebanyat, P., Ridder, N., Jager, A., Delve, R., Bekunda, M., \& Giller, K. 2010. Impacts of Heterogeneity in Soil Fertility on Legume-Finger Millet Productivity, Farmers' Targeting and Economics Benefit. Nutr Cycl Agorecosyst 87, 209-231.

Gerber, A. 2016. Short-Term Success versus Long-Term Failure : A SImulation-Based Approach for Understanding the Potencial of Zambia's Fertilizer Subsidi Program in Enhanching-Maize Availability. Sustainability. 8, $1038,12-17$.

Gilbert, J., \& Jaynea, T. 2017. Estimating the Enduring effect of Fertilizer Subsidies on Comercial Fertilizer Demand and Maize Production : Panel Data Evidence from Malawi. Journal of Agriculturian Economics, 70-97.

Ginige, S. R., \& Cooray, N. S. 2020. Modelling the Dynamic Impact of Fertilizer Subsidy on Paddy Production: Empirical Evidence from Sri Lanka. Journal of Reviews on Global Economics, 9, 293-307.

Gordon, I., \& Resosudarmo, B. (2019). A Sectoral Growth-Income Inequality Nexus in Indonesia. Regional Science Policy and Practice, 123-139.

Greene, W. 2012. Econometrics Analysis Seventh Edition. Boston: Prentice Hall.

Herath, H., Gunawardena, E., \& Wickramasinghe, W. 2013. The Impact of "Kethata Aruna" Fertilizer Subsidy Programme on Fertilizer Use and Paddy Production in Sri Lanka. Tropical Agricultural Research Vol. 25 (1), 14-26.

Hu, F., \& Antle, J. M. 1993. Agricultural Policy and Productivity: International Evidence. Review of Agricultural Economics, 15(3), 495-505.

Jaynea, T. S., Masona, N. M., Burkeb, W. J., \& Ariga, J. 2018. Review: Taking Stock of Africa's SecondGeneration Agricultural Input Subsidy Programs. Food Policy 75, 1-14.

Kanthilanka, H., \& Weerahewa, J. 2018. Do Price Subsidies Lead to Over Application of Fertilizers? An Analysis of Kethata-Aruna Program of Sri Lanka. Tropical Agricultural Research, vol. 30 (4): 133-142.

Kementerian Keuangan. 2015. Nota Keuangan APBN 2016. Jakarta: Kementrian Keuangan.

Kishi, M., Hirschhorn, N., Djajadisastra, M., Satterlee, L., Strowman, S., \& Dilts, R. 1995. Relationship of pesticide spraying to signs and symptoms in Indonesian Farmers. Scand J Work Environ Health, 124-133

Kis-Katos, K., \& Sparrow, R. 2015. Poverty, Labor Markets, and Trade Liberalization in Indonesia. Journal od Development Economics, 94-106.

Komarek, A. M., Drogue, S., Chenoune, R., Hawkins, J., Msangi, S., Belhouchette, H., \& Flichman, G. 2017. Agricultural Household Effects of Fertilizer Price Changes for Smallholder Farmers in Central Malawi. Agricultural Systems 154, 168-178.

Li, S., Zhang, Y., \& Zhang, Y. 2014. Fertilizer Indutry Subsidies in China : Who are the Beneficieries? China Agricultural Economic Review Vol 6. No. 3, 433-451.

Mulyadiana, A., Marwanti, S., \& Rahayu, W. 2018. Analysis of The Effectiveness of Fertilizer Subsidy Policy 
and Its Effect on Rice Production in Karanganyar Regency. OP Conf. Series: Earth and Environmental Science 142 .

Nguyen, A. T., Dzator, J., \& Nadolny, A. 2015. Does Contract Farming Improve Productivity and Income of Farmers : A Review of Theory And Evidence. The Journal of Developing Areas Volume 49 No. 6, 531-538.

Osorio, C. G., Abriningrum, D. E., Armas, E. B., \& Firdaus, M. 2011. Policy Research Working Paper: Who Is Benefiting from Fertilizer Subsidies in Indonesia? The World Bank East Asia and Pasific Region, Poverty Reduction and Economic Management Unit.

Pretty, J. 2008. Agricultural Sustainability : Concept, Principles, and Evidence. Philosophical Transactions of The Royal Society B : Biological Science 363, 447-465

Rahmanta, Prasetyo, A., \& Muda, I. 2019. It's True The Effectiveness of The Fertilizer Subsidy Policy And Its Effects on The Income of The Farmers? (Case In Indonesia). International. Journal of Sciencetific \& Technology Research Volume 8, Issue 6, 99-102.

Ramli, N. N., Shamsudin, M. N., Mohamed, M., \& Radam, A. 2012. The Impact of Fertilizer Subsidy on Malaysia Paddy/Rice Industry Using a System Dynamics Approach. International Journal of Social Science and Humanity, 2(3).

Ranathilaka, M. B., \& Arachchi, I. A. 2019. The Effect of Fertilizer Subsidy on Small-Scale Paddy Production in Sri Lanka: A Case in Hinguraggoda Divisional Secretariat Division in Polonnaruwa District. Sri Lanka Journal of Economic Research, vol. 6(2) pp.69-82.

Sharma, N., \& Singhvi, R. 2017. Effects of Chemical Fertilizers and Pesticides on Human Health and Environment: A Review. International Journal of Agriculture, Environment and Biotechnology , 675-679

Teka, A., \& Lee, S. K. 2020. Do Agricultural Package Programs Improve the Welfare of Rural People? Evidence from Smallholder Farmers in Ethiopia. Agriculture, 10(5), 190.

Ton, G., Vellema, W., Desiere, S., Weituschat, S., \& D'Haese, M. 2018. Contract farming for improving smallholder incomes: What can we learn from effectiveness studies? World Development 104, 46-64.

Wang, S. W., Manjur, B., Kim, J. G., \& Lee, W. K. 2019. Assessing Socio-Economic Impacts of Agricultural Subsidies: A Case Study from Bhutan. Sustainability, 11(12), 3266.

Wang, Y., Khor, L., \& Siddig, K. 2018. Socioeconomic Factors Determining Fertilizer Use in China for Different Crops: Same Factors, Different Effects. Agroeconomy Journal Volume 110 Issue 5, 1-7.

Wijetunga, C. S., \& Saito, K. 2017. Evaluating The Fertilizer Subsidy Reforms in The Rice Production Sector in Sri Lanka: a Simulation Analysis. Advances in Management and Applied Economics, 7(1), 31.

Wooldridge, J. 2001. Econometrics Analysis of Crosssection and Panel Data. London: MIT Press.

Wossen, T., Abdoulaye, T., Alene, A., Feleke, S., Gilbert, J. R., Manyong, V., \& Awotide, B. A. 2017. Productivity and Welfare Effects of Nigeria's e-Voucher-Based Input Subsidy Program. World Dev 97, 251-265. 